\title{
Employing Differently Abled Shop-Floor Employees in Confectionery Industry in Sri Lanka: An Ethnographic Narrative
}

\author{
Anuruddika Jayathilaka \\ University of Sri Jayewardenepura, Nugegoda, Sri Lanka \\ Email: anuruddikadec26@gmail.com
}

How to cite this paper: Jayathilaka, A. (2020). Employing Differently Abled ShopFloor Employees in Confectionery Industry in Sri Lanka: An Ethnographic Narrative. Open Journal of Business and Management, 8, 2472-2479.

https://doi.org/10.4236/ojbm.2020.86153

Received: August 30, 2020

Accepted: November 13, 2020

Published: November 16, 2020

Copyright ( 2020 by author(s) and Scientific Research Publishing Inc. This work is licensed under the Creative Commons Attribution International License (CC BY 4.0).

http://creativecommons.org/licenses/by/4.0/

\begin{abstract}
In the contemporary workplace, discrimination is avoided while diversity is promoted. Up to recent, past gender, race, and age were the topics taken into discussion. But recently a growing attention is visible in the corporate sector for providing employment opportunities for the differently-abled candidates to give equal opportunities to them as well. It is even against the law to discriminate against anyone in the workplace, because they have, or are assumed to have, a disability. Hence, it is essential to investigate on how the differently-abled employees are managed in the complex, turbulent corporate environment. In this research, in a journey of ethnographic narrative, I set out to narrate the stories of the differently-abled shop-floor employees in the confectionery industry, as their stories are within the context of Sri Lanka. As a good organizational ethnography can reveal and explore the intricacies, challenges, tensions, and choices of life in organizations, I employ organizational ethnography as the prime methodological approach of this study. Exploring and analyzing the daily lives of differently-abled shop-floor employeeswhile being part of their work life-paved the path to realize that employees with disabilities are capable of being an "employee" which the society expects. Finally, it could be concluded that unlike in managing the people without disabilities, it should be more towards sensitivity, which was observed and experienced throughout the research study.
\end{abstract}

\section{Keywords}

Employment, Differently-Abled, Confectionery Industry

\section{Introduction}

Background of the Study 
More than a billion people in the world experience disability. In Sri Lanka $8.6 \%$ from the total population is with difficulties, where only $29.4 \%$ is employed (Department of Census and Statistics, 2012). Providing employment opportunities, empowering and safeguarding their future will be a remedy to minimize the problems they face. Even though the world has identified the importance of the participation of differently abled persons in the labor force, yet addressing it in literature is rather rare. Still, how differently abled workers in the confectionery industry in Sri Lanka are employed, continues to remain outside of the scope of research studies.

\section{The research problem/research question}

"How differently abled shop-floor employees are employed in confectionery industry in Sri Lanka?" is the research question that I am focusing on throughout the research study. My research study aims: firstly, to explore how differently abled are employed in the Confectionery Industry in Sri Lanka; secondly, yet most importantly, to write the (unwritten) stories of differently abled employees, specially their daily performance at the factory floor.

\section{Literature Review}

The Act for "The Protection of the Rights of Persons with Disabilities Act No. 28 of 1996" section 37 reads: "person with disability means any person who, as a result of any deficiency in his physical or mental capabilities, whether congenital or not, is unable by himself to ensure for himself, wholly or partly, the necessities of life" (National policy on Disability for Sri Lanka, 2003: p. 9). This definition is a reasonably broader one, encompassing both medical and socio-economic aspects of disability. There is no perfect definition of "disability" exists, as the concept is subject to social interpretation and people may be legally disabled in some jurisdictions but not in others (Lewis \& Allee, 1992).

Throughout centuries the attitude towards people with disabilities changed drastically from "affliction" to "differently abled". The words that we use to describe people with disabilities have changed over time; different terms have been used for differently abled people in different times and places. The latest way of addressing people with disabilities is by using "People first language", which is used to speak appropriately and respectfully about an individual with a disability. People first language emphasizes the person first not the disability.

The perception by many that being differently abled is a medical issue (medical model). In the medical model, management of the disability is aimed at a "cure", or the individual's adjustment and behavioral change that would lead to an "almost-cure" or effective cure. In the medical model, medical care is viewed as the main issue, and at the political level, the principal response is that of modifying. Another model that is concerned together with differently abled is social model of disability, which sees "disability" as a socially created problem and a matter of the full integration of individuals into society. In this model, rather than as an attribute of an individual, disability is seen as a complex collection of 
conditions, created by the social environment. The social construction of disability offers a new lens for understanding ability and disability as a social construction that frames how society understands and interacts with individuals who behave in ways that are different from the norm. It is a tool to assist in recognizing how ability is framed so that people can recognize and work toward more equitable, inclusive practices and perceptions of individuals who are different (Dray, 2008).

For people with disability, participation in an activity, fellowship with others and an occupational identity are more important, because these individuals have become increasingly marginalized group in the contemporary working life, with its great demands for education, flexibility and productivity (Boman et al., 2014). Historically, work is one of the sites where the notion of disability is elaborated, it may be either seen as a place of rehabilitation where disabled persons may find or re-find a feeling of social utility and self-realization; or a setting where situations of disability appear, because performance demands might reveal or even engender limitations that then become problematic (Bertrand et al., 2014). But with the enhancement of social norms, as argued by Saad Nagi, William McBroom and John Collette (1972), "Work remains an important and often a necessary aspect of life for persons with impairments. Furthermore, many impaired workers recover sufficient capacity for competitive employment."

When it comes to the confectionery industry it is stated that, "It is also the case that training related to food hygiene and occupational health and safety is important in a food manufacturing context". It is implied that the food hygiene and health of the employee is much concerned in confectionary industry as well. Especially when it comes to mentally disabled (referring to autism), "Kids with autism need to have a reason for doing everything. Things need to make sense. Behaviors related to hygiene, such as brushing teeth, washing their body and hair, brushing their hair, wearing clean clothes all seem rather arbitrary to them". Since the confectionery industry is highly concerned on hygiene of the employees the probability to hire an employ a differently abled (specially a mentally disabled) is significantly less.

\section{Methodology}

The prime methodological approach of this research study was organizational ethnography. Rosen (1991) understands organizational ethnography to be distinctive because it is concerned with social relations that are related to certain goal directed activities. He suggests that the rules, strategies and meanings within a structured work situation are different from those that affect other areas of social life. Koot, 1995 defines organizational ethnography as the art of exploring the complexities of everyday organizational life through immersion (as cited in Ybema \& Kamsteeg, 2009). Goodall (1991) is emphatic that organizational ethnography requires a well-balanced concern with the play between context, self and other as they thread themselves across the warp and weft of communication 
(as cited at Linstead, 2017). Organizational ethnography is also viewed as a methodology which joins political ethnography, educational ethnography and other such whose marking designates the kind of setting in which the ethnography is to be carried out, as well as, at times, the disciplinary domain that gives it a home by Yanow (2012). Cunliffe (2010) argues that good organizational ethnographies can reveal and explore the intricacies, challenges, tensions, and choices of life in organizations.

Being close to the "natives" - or even being natives themselves, as in the case of at home ethnography (Alvesson, 2009 as cited in Ybema \& Kamsteeg, 2009)_organizational ethnographers may have an easier access to culture members' own perspectives, while simultaneously experiencing more difficulties in divesting themselves of taken-for-granted understandings (Ybema \& Kamsteeg, 2009). I preferred to be a "participant as observer" while playing an overt role. The observational work was owned by a conglomerate and physically located two hours away from the University of Sri Jayewardenepura. Being an organizational ethnographer, while working as a voluntary based employee for sixteen days, was socially interacting with the fellow seventeen differently abled employees rather than observing them as a separate unit/person.

I conducted informal and unstructured interviews, with the three supervisors and the manager, and incorporated both observing and writing up "field notes" because of the time constraint and limited resources. Especially I had to write up field notes because I could not keep breaking off conversations to make jottings in the notebook. Turning observation into data involves the issue of how to select from the material and impression generated from the field work. According to Seneviratne (2010), the ethnographer has to engage with the question of how diverse and experimental material can become the kind of data which can be used to construct convincing and meaningful arguments. She further continues that such decisions should be based on grounded critical judgements of what each can offer in relation to the research question and their context. I decided to incorporate my own perceptions, experiences and interpretations into the field notes. Detailed descriptions of what happened in the field; my own feelings were integrated in the field notes. I also did consider about taking photographs as I believed that using photographs will highlight what I try to bring up. This is seconded by Emmison and Smith (2000), "photographs may be helpful sometimes in recording the seen dimensions of social life. Usually they are not necessary" (as cited in Mason, 2002). For the analysis narrative approach was used to narrate the untold and unheard story.

\section{Findings and Discussion}

The part of this narrative is woven around the lives of shop-floor employees of Mithuru Sevana confectionery factory begins with a journey to the shop-floor, where they work. When it comes to the work engagement, Tessler and Schwartz (1972) and Williams and Williams (1983) researches indicate that in many cases 
individuals, who need help, do not ask for it (as cited in Barclay \& Markel, 2009). I experienced that the morning meeting held employees to express themselves while getting feedback from the supervisors and manager. Indeed, engaging employees is one of the top five most important challenges for management (Wah, 1999 as cited in Attridge, 2009) but with the help of the patient supervisors and manager the employees with special needs were managed more than perfectly. Barclay \& Markel (2009) say that when defining when someone can perform the essential aspects of a job may be more difficult in the case of psychiatric disability. Thus, most of the time work was allocated according to the preference of the employees and the consent of the manager or the supervisors. Barling, Kelloway and Frone (2005) says that the specific elements and tasks of work can be redesigned to use the employee's strengths and employees can be placed into jobs that better match their abilities and talents-or what has been called personenvironment fit (Attridge, 2009). Through better job designing and work allocation better employee engagement is achieved in the shop floor. Low work productivity and employee disengagement are both associated with experiencing low levels of support from supervisors and coworkers (Attridge, 2009). Despite of all the work that the supervisors and manager have they are very supportive to the shop-floor employees while managing them smoothly.

To avoid creating difficult job demands and stressful working conditions, efforts are taken such as removing problematic or disliked parts of job tasks and technical operations, adopting more ergonomic workplace equipment, adding some flexibility to work schedules and workload, improving role clarity and decision-making authority of workers, and fostering opportunities for positive social relationships at work (Warr, 2005 as cited in Attridge, 2009). By considering all the efforts mentioned above, the work for the differently abled is neither difficult nor stressful jobs. Pitney Bowes has been measuring employee engagement or more than a decade and has integrated engagement-enhancing practices into the everyday culture of the company (Attridge, 2009), just like in the factory floor.

Apart from being employed very employee should maintain a record book with them to record the factory work they have. Even though this controlling procedures look like violating the employee's privacy it is not parse because it is a step taken by the employer to improve the employees' capabilities in a way. Perrson and Hansson (2003) have explored the ethical criteria for determining under what conditions an individual's privacy could be overridden (as cited in Barclay \& Markel, 2009). Even though they have not specifically identified about the mentally disabled employees they argue that privacy should only be violated if it is in the best interest of the employer or the employee for a work related reason and that the intrusion should be minimal as possible (Barclay \& Markel, 2009).

I must mention that the leadership style and support is crucial for encouraging employee engagement (Attridge, 2009) as well as in managing employees. 
The leadership of the manager and the three supervisors should be highlighted with regard to completing a difficult task. As per Quick, Macik-Frey, \& Cooper (2007) an important leadership attributes include being authentic and showing emotional competence with others (as cited in Attridge, 2009). The result of this style of leadership is often that employees develop greater trust in management and have an improved sense of self-efficacy, both of which are factors that are strongly associated with wellbeing and productivity (Attridge, 2009).

Stefan (2002) reports that, many employers and colleagues assume that individuals with severe mental illness are incapable of employment. But it was experienced that it is not true, when working with the differently abled employees hand to hand. They are capable of working according to the instructions provided. The only thing that should be kept in mind is to manage the employees with disabilities with concern, by taking their emotional state seriously.

\section{Conclusion}

As stated earlier, narrating the stories of differently abled shop-floor employees in the confectionery industry is what I see as the most significant contribution of my study. However, their stories as I narrate here might be different from what they might narrate. My writing does not claim to be fully representative of their lives, because I am not a full time factory floor worker, only a young female undergraduate research student, who incorporated organizational ethnography, by working at the factory floor only for sixteen days, as a voluntary based employee, striving to narrate the stories of their lives. I hope this study will contribute to the existing literature relating to the employment of differently abled employees as well to the employers who are willing to provide employment opportunities for the persons with disabilities. Further, I believe that my effort has contributed in terms of seeking truth from facts. As well the existing literature aims on the countries others than Sri Lanka and also other industries other than Confectionery Industry. Hence, I believe this research study will contribute to the literature relating to how differently abled shop-floor employees are employed in confectionery industry in Sri Lanka.

When it comes to the limitations I faced, their convenience was considered first when I was engaged in the data gathering process. Due to their busy schedules along with the factory shift, my field visit plan was adjusted accordingly. Time consuming travelling from the University to the factory also was a limitation as an undergraduate. While being employed in the shop-floor, there was a risk of being rejected. Hence, I had to be patient and was a tough and difficult process in collecting and gathering data from the participants. Even though I made an attempt to follow the rules and write down everything I heard and record every conversation it did not always lead to a coherent output; as well the manager was not pleased to allow me to record their conversations. Thus, I had to engage in making field notes fulltime. In the analysis, I was always tried to covert my own experience into words. But, because this is the first research 
study experience as an undergraduate student I wonder whether I was capable of achieving my objective successfully by following the supervisor's guidance and advices.

The intention of the study is to explore how the differently abled employees are managed in the confectionery industry in Sri Lanka. I suggest for the future researches to address the same question in the aspects which I was not able to achieve due to the restrictions and limitations I faced as a young female undergraduate student who was conducting the first research study. Also, by moving further since there is a lack of research study done relating to employment of differently abled in the Sri Lankan context, there is a gap remaining to be filled with respect to the other industries where the opportunities are provided. As well in order to encourage more employers and industries who have not yet taken the initiatives to provide employment opportunities, research studies can be conducted focusing on the feasibility of providing employment opportunities.

\section{Conflicts of Interest}

The author declares no conflicts of interest regarding the publication of this paper.

\section{References}

Attridge, M. (2009). Measuring and Employing Employee Work Engagement: A Review of the Research and Business Literature. Journal of Workplace Behavioral Health, 24, 383-398. https://doi.org/10.1080/15555240903188398

Barclay, L., \& Markel, K. (2009). Ethical Fairness and Human Rights: The Treatment of Employees with Psychiatric Disabilities. Journal of Business Ethics, 85, Article No. 333. https://doi.org/10.1007/s10551-008-9773-5

Bertrand, L., Caradec, V., \& Eideliman, J.-S. (2014). Situating Disability: A Recognition of "Disabled Workers" in France. Alter, 8, 269-281. https://doi.org/10.1016/j.alter.2014.09.006

Boman, T., Kjellberg, A., Danermark, B., \& Boman, E. (2014). Employment Opportunities for Persons with Disabilities. Alter, 9, 116-129. https://doi.org/10.1016/j.alter.2014.11.003

Cunliffe, A. L. (2010). Retelling Tales of the Field: In Search of Organizational Ethnography 20 Years On. Organizational Research Methods, 13, 224-237. https://doi.org/10.1177/1094428109340041

Department of Census and Statistics (2012). Disability in Sri Lanka.

Dray, B. J. (2008). Social Construction of Disability.

Lewis, G., \& Allee, C. (1992). The Impact of Disabilities on Federal Career Success. Public Administration Review, 52, 389-397. https://doi.org/10.2307/3110399

Linstead, S. A. (2017). Feeling the Reel of the Real: Framing the Play of Critically Affective Organizational Research between Art and the Everyday. Organization Studies, 39, 319-344. https://doi.org/10.1177/0170840617717552

Mason, J. (2002). Qualitative Research. London: SAGE Publications.

Nagi, S., McBroom, W., \& Collett, J. (1972). Work, Employment and the Disabled. The American Journal of Economics and Sociology, 31, 21-34. 
https://doi.org/10.1111/j.1536-7150.1972.tb03139.x

National Policy on Disability for Sri Lanka (2003).

Seneviratne, S. J. (2010). Producing and (Re) Producing? An Ethnographic Narrative of Female Plantation and Apparel Workers of Sri Lanka.

Yanow, D. (2012). Organizational Ethnography between Toolbox and World-Making. Journal of Organizational Ethnography, 1, 31-42. https://doi.org/10.1108/202466741211220633

Ybema, S., \& Kamsteeg, F. (2009). Making the Familiar Strange: A Case for Disengaged Organizational Ethnography. In Organizational Ethnography: Studying the Complexities of Everyday Life (pp. 101-119). London: Sage. 